\title{
COMPARATIVE EVALUATION OF THE KOMODO DRAGON (Varanus komodoensis) AND THE GREEN IGUANA (Iguana iguana) SKULL BY THREE-DIMENSIONAL COMPUTED TOMOGRAPHIC RECONSTRUCTION
}

\author{
Sara Pérez¹, Mario Encinoso ${ }^{1}$, Manuel Morales$^{1}$, Alberto Arencibia $^{2}$, Alejandro Suárez-Bonnet $^{3}$, Eligia González-Rodríguez¹, \\ J. Raduan Jaber ${ }^{2 *}$ \\ ${ }^{1}$ Instituto Universitario de Investigaciones Biomedicasy Sanitarias (IUIBS), ${ }^{2}$ Departamento de Morfologia, Facultad deVeterinaria, Universidad \\ de Las Palmas de Gran Canaria. Trasmontaña, Arucas, 35413 Las Palmas, Spain, ${ }^{3}$ Department of Pathobiology, The Royal Veterinary College, \\ University of London, Hertfordshire, AL97TA, London, United Kingdom \\ ${ }^{*}$ Corresponding author, E-mail: joseraduan.jaber@ulpgc.es
}

\begin{abstract}
The purpose of this paper was to do a comparative evaluation of the skull of two species of lizards, the Komodo dragon (Varanus komodoensis) and the Green Iguana (Iguana iguana), by three-dimensional computed tomographic reconstruction. Images provided by this method give excellent anatomic detail of the skull. Therefore, essential differences in the configuration of the orbit and the lateral bones of the neurocranium were visualized in lateral and dorsal reconstructed images. The images obtained by tridimensional computed tomographic reconstruction can be a valuable diagnostic aid for the clinical evaluation of several head disturbances in lizards.
\end{abstract}

Key words: computed tomography; 3D reconstruction; anatomy; skull; lizards

\section{Introduction}

Reptiles are a peculiar kind of animal characterized by corneous scales that protect them from desiccation (1). This class of animals is divided into four orders: Chelonians, which comprise turtles, tortoises, and terrapins; Crocodilla, whose specimens are alligators and crocodiles; Rhynchocephalia, with tuataras; and Squamate, represented by two suborders: Ophidia (snakes) and Lacertilia (lizards) (2). Some of these species have become very common in recent years as pets, which became a challenge for veterinary

Received:21 April 2021

Accepted for publication: 1 July 2021 clinicians since they have to overcome the lack of a reference system similar to canine and feline medicine (3). Thus, it is essential to know and understand their anatomy for an adequate diagnosis and treatment of diseases $(4,5)$.

The introduction of modern diagnostic imaging techniques such as $\mathrm{x}$-ray computed tomography (CT) has been an essential support to specialists. It has afforded the chance to study anatomy and apply it in the clinical features of these species (6). Furthermore, compared with conventional radiography, the digital image format of $\mathrm{CT}$ results in improved tissue contrast. In addition, manipulation of the greyscale allows optimal visualization of all tissues within the slice. These characteristics are 
advantageous to obtain anatomical information about different regions of the animal body. The recent advances in CT technology include applying computer software to generate three-dimensional (3D) construction of an area of anatomic interest. This technique requires multiple thin section images, and the advantages of this process are that anatomical detail is improved, and can image bony structures with different degrees of rotation (6). CT reconstruction has already been used in morphofunctional studies performed in the Savannah monitor (7) and American Alligator (8). However, there are no reports concerning comparative anatomy of the skull of different species of reptiles by three-dimensional reconstructed $\mathrm{CT}$ to the author's knowledge. The few descriptions performed in these species only deal with cross-sectional studies such as those done in the Boa constrictor (4), the Green iguana, the Common tegu, and the Bearded dragon head (5), and more recently, an anatomic interactive atlas of the loggerhead sea turtle head using images obtained via osteology, gross dissections, and computed tomography (9). Therefore, this study aimed to describe and compare the normal anatomy of two species of lizards, the Komodo dragon (Varanus komodoensis) and Green iguana (Iguana iguana) skull performing threedimensional $\mathrm{CT}$ reconstruction.

\section{Materials and methods}

\section{Animals}

Two adult female Komodo dragons (Varanus komodoensis) and two male green iguanas (Iguana iguana) were imaged at the Veterinary Clinic Hospital of Las Palmas de Gran Canaria University. No physical examination abnormalities were detected before the study. The reptiles owner was informed of the study and signed consent for participation in it.

\section{CT technique}

Sequential transverse CT slices were obtained using a 16-slice helical CT scanner (Toshiba Astelion, Toshiba Medical System, Madrid, Spain). The animals were positioned symmetrically in ventral recumbency on the CT couch. A standard clinical protocol $(120 \mathrm{kVp}, 80 \mathrm{~mA}, 512$ X 512 acquisition matrix, 1809 × 858 field of view, a spiral pitch factor of 0.94 , and a gantry rotation of $1.5 \mathrm{~s})$ was used to acquire sequential transverse CT images of $1 \mathrm{~mm}$ thickness slice. The original transverse data were stored and transferred to the CT workstation. No CT density or anatomic variations were detected in the head of the reptiles used in the investigation. In this study, we applied two CT windows by adjusting the window widths (WW) and window levels (WL) to appreciate the CT appearance of the head structures: a bone window setting (WW $=1500 ; \mathrm{WL}=300)$ and a soft tissue window setting $(\mathrm{WW}=350 ; \mathrm{WL}=40)$. The original data were used to generate head volume-rendered reconstructed images after manual editing of the transverse CT images to remove soft tissues using a standard Dicom 3D format (OsiriX MD, Geneva, Switzerland).

\section{Results}

Head three-dimensional volume-rendered reconstruction images corresponding to dorsal (Fig. 1, 4) and ventral (Fig. 2, 5) views and the left lateral view (Fig.3, 6) of the Komodo dragon and green iguana head. Volume-rendered reconstructed CT images showed excellent visualization of the bones that comprised the skull. Therefore, in the Komodo dragon head, the orbit was cranial and ventrally delimited by the lacrimal, the prefrontal, and the jugal bones (Figs. 1,3). Besides, this technique allowed us to visualize the relation between this last and the ectopterygoid bone (Fig.3). Caudodorsally, the junction of the postorbital and postfrontal bones could be observed in the lateral and dorsal reconstructed CT images (Figs. 1,3). Moreover, the ventral CT reconstructed image identified the intersection of the frontal and the parietal bones. The different bones of the neurocranium, such as the parabasisphenoid, the basioccipital, and the prootic bones, were easily identifiable (Fig. 2). Besides, the laminar disposition of the vomer and how it supports the septomaxilla were observed (Fig.2). The junction between the premaxilla and the maxilla with the tooth arranged in a straight row was identified in the lateral and ventral reconstructed CT images (Figs. 2,3). The jaw showed a straight tooth row and a curved ventral border in the lateral reconstructed CT image. In addition, the coronoid process was quite prominent, and the surangu- 
lar and articular bones were observed extending caudally (Fig. 3). The ventral reconstructed image showed excellent pterygoid visualization, which is flat and " $y$ " shaped bone. This one had a rounded process, where the caudal border of the palatine process contacts. This view also depicted the junction between the parabasisphenoid, the prootic, and the basioccipital bones. The ventral portion of this last bone constituted the occipital condyle (Fig. 2).

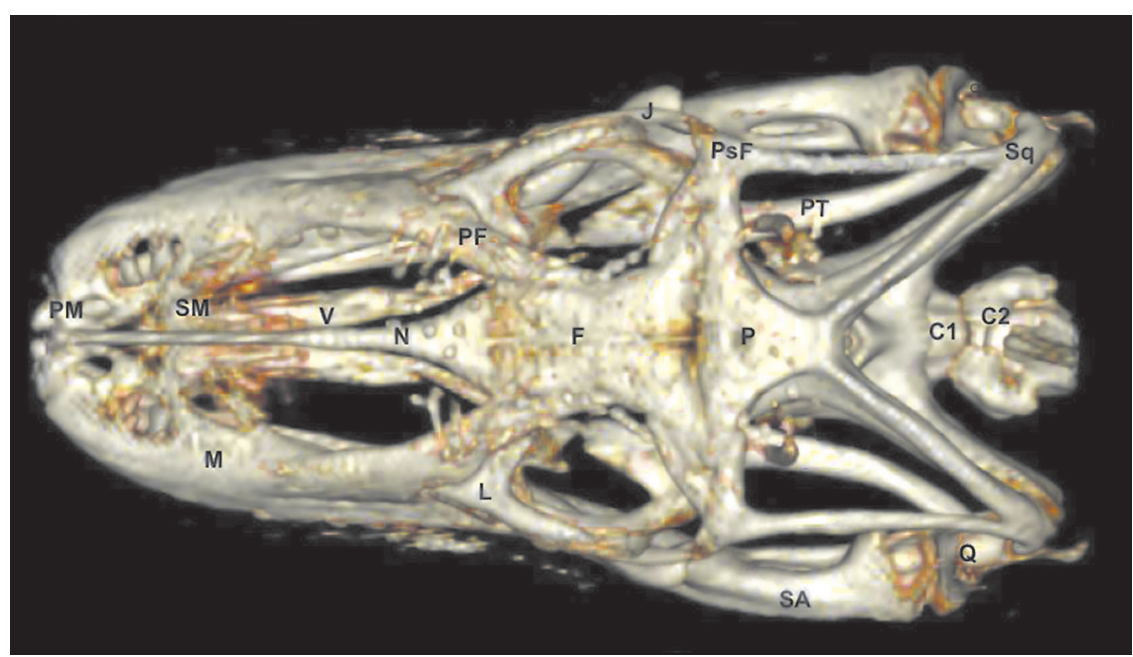

Figure 1: Three-dimensional volume-rendered reconstruction image of the normal Komodo dragon head. Dorsal aspect. PM: Premaxillary bone. M: Maxillary bone. SM: Septomaxilla. N: Nasal bone. V: Vomer. PF: Prefrontal bone. F: Frontal bone. L: Lacrimal bone. J: Jugal bone. Q: Quadrate bone. Sq: Squamosal. PsF: Postfrontal+postorbital. P: Parietal. PT: Pterygoid bone. SA: Surangular bone. C1: First cervical vertebra. C2: Second cervical vertebra
Figure 2: Three-dimensional volume-rendered reconstruction image of the normal Komodo dragon head. Ventral aspect. D: Dentary bone. SA: Surangular bone. A: Articular bone. SM: Septomaxilla. V Vomer. PL: Palatine bone. PT: Pterygoid bone. PsF: Postfrontal+postorbital bone. $\mathrm{N}$ : Nasal bone. F: Frontal bone. P: Parietal bone. PB: Parabasisphenoid bone. BO: Basioccipital bone. OC: Occipital condyle. PRO: Prootic bone. Q: Quadrate bone.

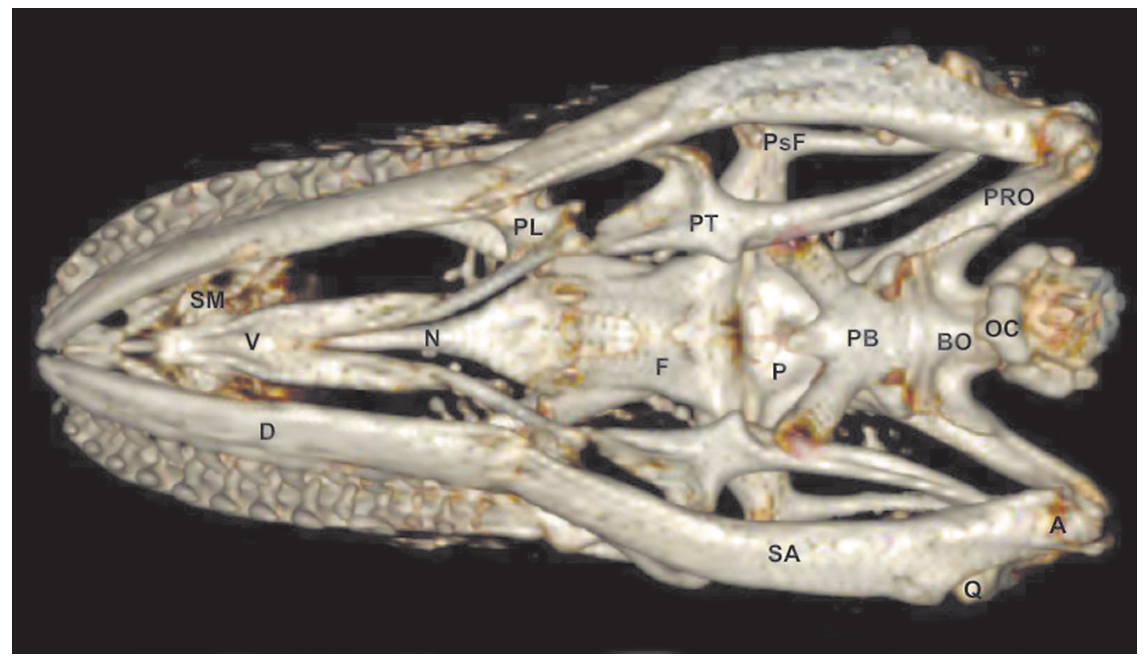

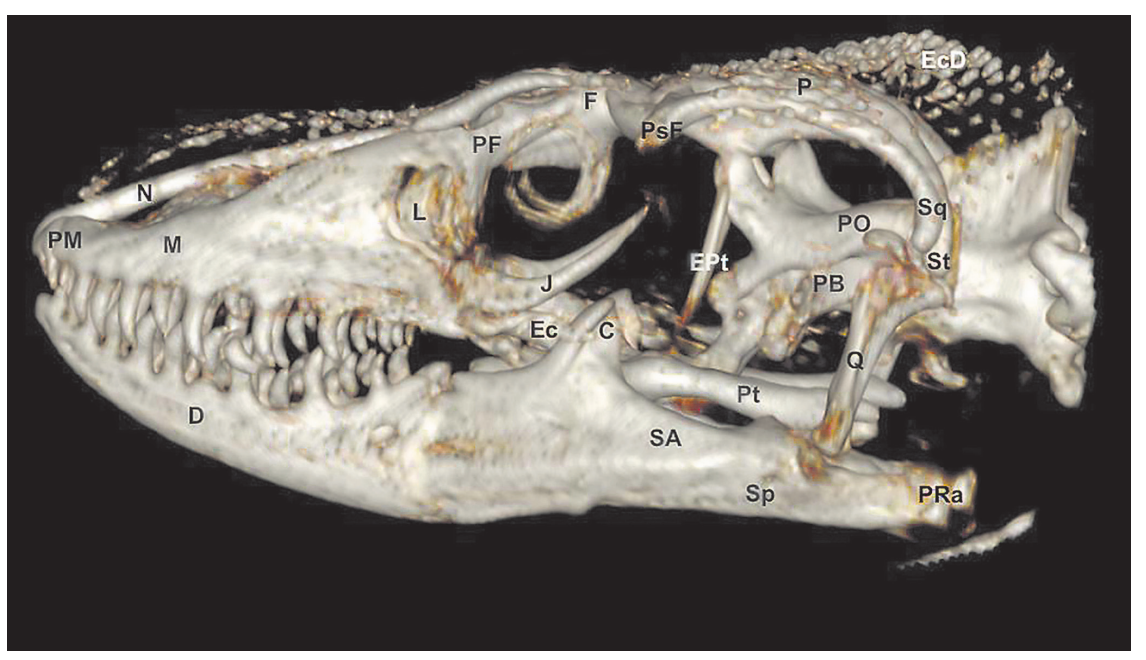

Figure 3: Three-dimensional volume-rendered reconstruction image of the normal Komodo dragon head. Lateral aspect. PM: Premaxillary bone. M: Maxillary bone. PF: Prefrontal bone. N: Nasal bone. F: Frontal bone. L: Lacrimal bone. J: Jugal bone. Ec: Ectopterygoid bone. Pt: Pterygoid bone. EPt: Epipterygoid. Q: Quadrate bone. St: Supratemporal. Sq: Squamosal. PsF: Postfrontal+postorbital. PRO: Prootic. PB: Parabasisphenoid bone. P: Parietalbone. D: Dentary bone. C: Coronoid bone. SA: Surangular bone. Sp: Splenial. PRa: Retroarticular process. EcD: Osteoderms 
Concerning the green iguana head, the lateral reconstructed images showed a high and domed skull (Fig. 6). In contrast with the Komodo dragon head, the orbit of the green iguana was closed by the postfrontal and the postorbital bone junction, which was extended to the posterior margins of bony orbits till articulate with the jugal bone (Figs. 4,6). Therefore, the jugal formed the lateral wall of the bony orbit and was joined with lacrimal (dorsally), maxillary (ventrally), ectopterygoid (medially), postorbital (caudodorsally), and squamosal (caudally) (Fig. 6). This view identified frontal, parietal, and postfrontal bones (Fig. 6). Moreover, the prefrontal bones connecting rostrally maxillary and nasal bones, laterally to lacrimal bones, and caudodorsally to frontal bones were also identified in the dorsal view (Fig. 4). This prefrontal bone participated in the dorsal and rostral orbit walls (Figs. 4,6). This lateral view showed the junction between squamosal, ectopterygoid, epipterygoid, pterygoid, quadrate, and prootic bones. This last one had a square shape and formed the neurocranium's lateral walls, which were also well visualized in ventral reconstructed images (Fig. 5). Thus, the junction between the basioccipital, the parabasisphenoid bones, and its lateral connection with the pterygoid could be observed. These ventral and lateral reconstructed images showed the bones composing the jaw. Thus, the dentary, the coronoid, the surangular, and the articular bones were evident in these views.
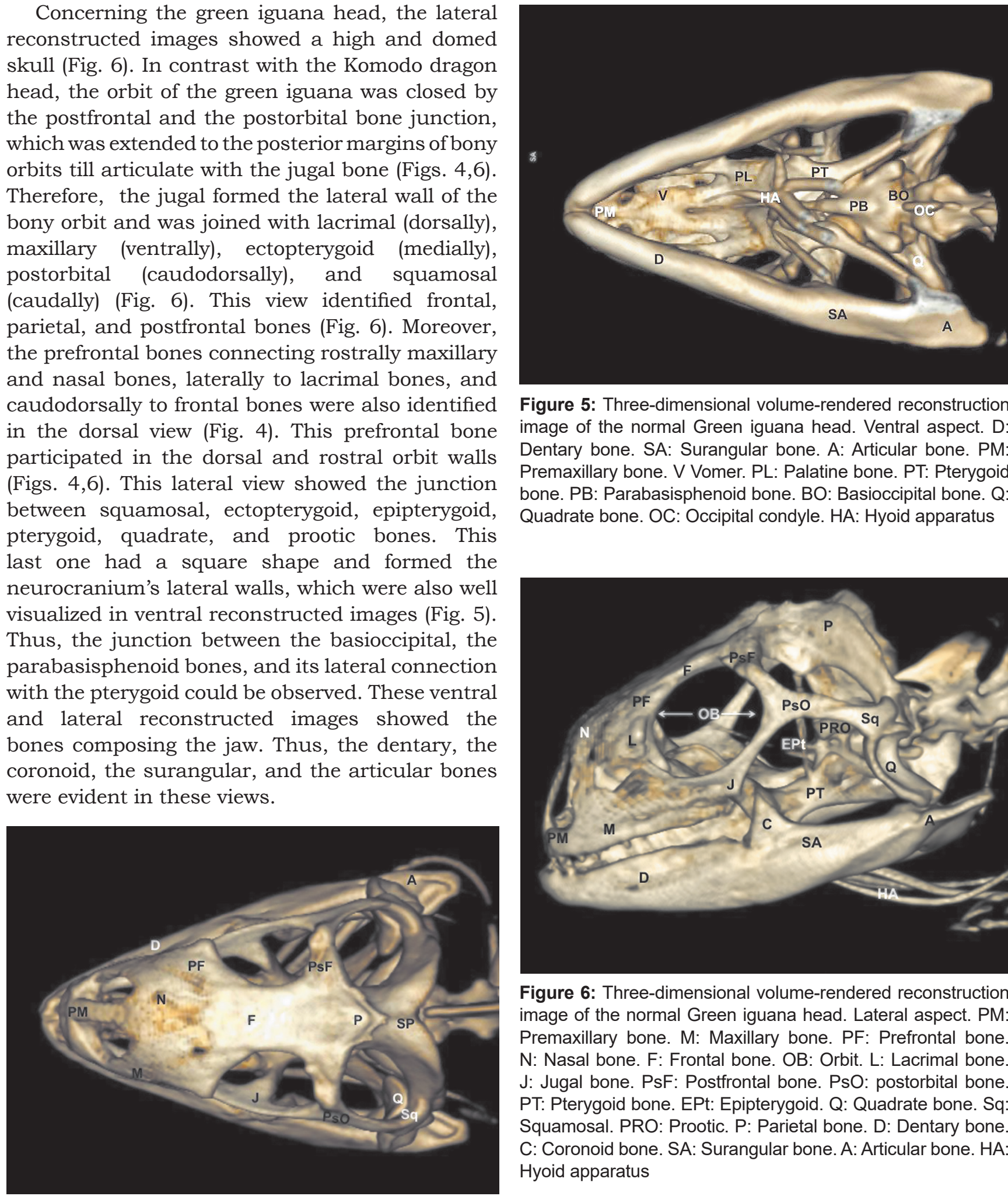

Figure 5: Three-dimensional volume-rendered reconstruction image of the normal Green iguana head. Ventral aspect. D: Dentary bone. SA: Surangular bone. A: Articular bone. PM: Premaxillary bone. V Vomer. PL: Palatine bone. PT: Pterygoid bone. PB: Parabasisphenoid bone. BO: Basioccipital bone. Q: Quadrate bone. OC: Occipital condyle. HA: Hyoid apparatus

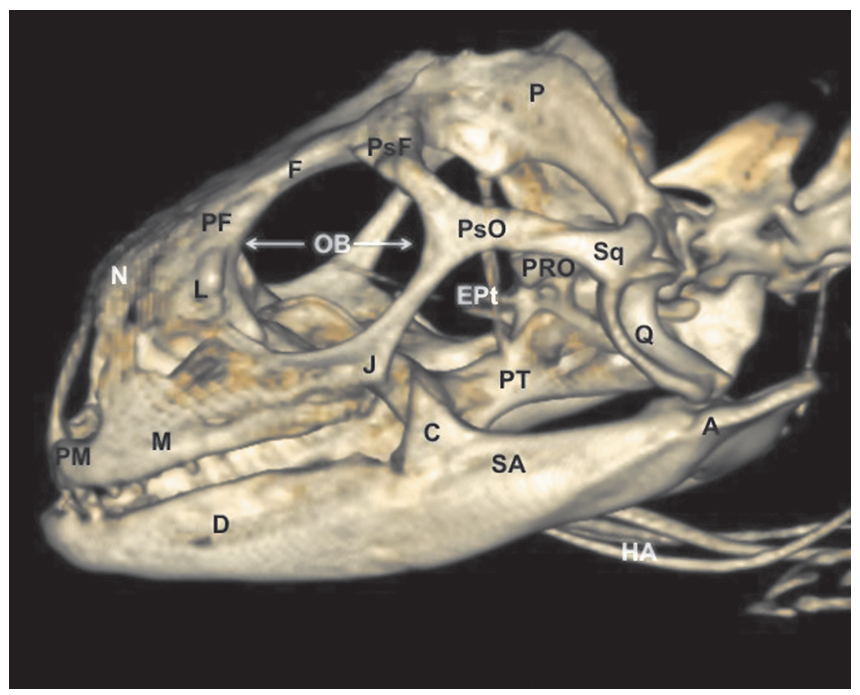

Figure 6: Three-dimensional volume-rendered reconstruction image of the normal Green iguana head. Lateral aspect. PM: Premaxillary bone. M: Maxillary bone. PF: Prefrontal bone. $\mathrm{N}$ : Nasal bone. F: Frontal bone. OB: Orbit. L: Lacrimal bone. $\mathrm{J}$ : Jugal bone. PsF: Postfrontal bone. PsO: postorbital bone. PT: Pterygoid bone. EPt: Epipterygoid. Q: Quadrate bone. Sq: Squamosal. PRO: Prootic. P: Parietal bone. D: Dentary bone. C: Coronoid bone. SA: Surangular bone. A: Articular bone. HA: Hyoid apparatus

Figure 4: Three-dimensional volume-rendered reconstruction image of the normal Green iguana head. Dorsal aspect. PM: Premaxillary bone. M: Maxillary bone. N: Nasal bone. PF: Prefrontal bone. F: Frontal bone. J: Jugal bone. Q: Quadrate bone. Sq: Squamosal. PsF: Postfrontal. PsO: Postorbital. P: Parietal. SP: Supraoccipital bone. D: Dentary bone. A: Articular bone

\section{Discussion}

The arrival of imaging techniques to reptile medicine has improved veterinary medicine diagnosis (5-9). Traditionally, radiography (10) 
and ultrasonography (11) have been applied to obtain information on the bony and the main softtissue structures of different animal regions. In contrast, computed tomography has become the preferred imaging technique due to its considerable advantages (11). Hence, last-generation CT equipment gives fast imaging acquisition, body sections from different tomographic planes, fair anatomic resolution without superimposition, and excellent tissue-like differentiation $(5,9)$.

Three-dimensional CT reconstruction is a valuable procedure, which is infrequently applied in veterinary medicine. The data collection requires multiple parallel thin sections, which are all obtained at the same gantry tilt. Ideally, a high-speed scanner such as the scanning beam 'cine' CT system can produce a rapid sequence of quality thin sections to minimize motion artifact (12). This procedure can image the surface of bony structures with different degrees of rotation without the superimposition of soft tissues $(12,13,14)$.

As in other lizards, the Komodo dragon and the Green Iguana skull are complex structures composed of different bones with significant disparity. However, in contrast with other reports that did radiographs $(4,5)$, the use of reconstructed images of the skull avoided the superimposing of the bilateral structures of the snout and neurocranium to give excellent visualization of the junction between bones that comprise the head. Thus, lateral and dorsal reconstructed images visualized essential differences between the species studied. Therefore, an enormous difference in the orbit composition was observed in the species studied, especially along the posterior margin of the orbit, where it was closed (Green iguana) or open (Komodo dragon). This fact was determined by variations in the shape, size, and presence of the jugal bone and variations in the postorbital and postfrontal bones, as explained by Daza and Bauer (15). Besides, in the lateral side of the neurocranium could be identified the prootic bone, which had a square shape in the Green iguana. In contrast, it was tubular in the Komodo dragon.

Other investigations have studied the comparative and morphometrics features of the skull in terrestrial mammals by three-dimensional computed tomographic reconstruction (16). Nonetheless, in our study, anatomical measurements of the head and mandible were not performed since the number of specimens studied was scarce to perform statistical analysis.

In conclusion, we have attempted to describe our findings on recognizable structures in alive reptiles, but further studies are necessary to define the ultimate limits of 3D CT reconstruction for essential morphologic imaging and interpretation of animals with clinical signs. Nevertheless, the CT reconstructed images obtained in this study facilitated an adequate anatomical understanding of the Komodo dragon and Green iguana skull. This information could be used to diagnose disorders involving the head of lizards, such as metabolic bone diseases, fractures, and neoplasias.

\section{Acknowledgment}

In loving memory of Alvaro Domingo Rodriguez Garcia. We also thank Marisa Mohamad for her support and constructive comments.

Authors declare that no any conflict of interest exists.

\section{References}

1. Gumpenberger M. Diagnostic imaging of reproductive tract disorders in reptiles. Vet Clin North Am Exot Anim Pract 2017; 20(2): 327-43.

2. Hernández C, Peloso PL, Bolivar W, Daza JD. Skull morphology of the lizard Ptychoglossus vallensis (Squamata:Alopoglossidae) with comments on the variation within Gymnophthalmoidea. Anat Rec 2019; 302(7): 1074-92.

3. Banzato T, Hellebuyck T, Van Caelenberg A, Saunders JH, Zotti A. A review of diagnostic imaging of snakes and lizards. Vet Rec 2013; 173(2): 439.

4. Banzato T, Russo E, Di Toma A, Palmisano $\mathrm{G}$, Zotti A. Anatomic imaging of the Boa constrictor head: a comparison between radiography, computed tomography and cadaver anatomy. Am J Vet Res 2011; 72(12): 1592-9.

5. Banzato T, Selleri P, Veladiano IA, Martin A, Zanetti E, Zotti A. Comparative evaluation of the cadaveric, radiographic and computed tomographic anatomy of the heads of green iguana (Iguana iguana), common tegu (Tupinambis merianae) and bearded dragon (Pogona vitticeps). BMC Vet Res 2012; 8: e53. doi: 10.1186/1746-6148-8-53

6. Lauridsen H, Hansen $\mathrm{K}$, Wang $\mathrm{T}$, et al. Inside out: modern imaging techniques to reveal 
animal anatomy. PLoS ONE 2011; 6(3): e17879. doi: $10.1371 /$ journal.pone.0017879

7. Wilken AT, Middleton KM, Sellers KC, Cost IN, Holliday CM. The roles of joint tissues and jaw muscles in palatal biomechanics of the savannah monitor (Varanus exanthematicus) and their significance for cranial kinesis. J Exp Biol 2019; 222 (Pt 18): jeb201459.

8. Holliday CM, Tsai HP, Skiljan RJ, George ID, Pathan S. A 3D interactive model and atlas of the jaw musculature of Alligator mississippiensis. PLoS One 2013; 8(6): e62806. doi: 10.1371/journal.pone.0062806

9. Arencibia A, Melian A, Oros J. Anatomic interactive atlas of the loggerhead sea turtle (Caretta caretta) head. Animals 2021; 11(1): e198. doi: 10.3390/ani11010198

10. Knipe FM. Principles of neurological imaging of exotic animal species. Vet Clin North Am Exot Anim Pract 2007; 10(3): 893-907.

11. Krautwald-Junghanns ME, Pees M, Reese S. Diagnostic imaging of exotic pets. Hannover : Schlutersche, 2011: 310-459.
12. Arencibia A, Corbera JA, Ramírez G, et al. Anatomical assessment of the thorax in the neonatal foal using computed tomography angiography, sectional anatomy and gross dissections. Animals 2020; 10(6): e1045. doi: 10.3390/ ani10061045

13. Zafra R, Carrascosa C, Suarez-Bonnet A, et al. Three-dimensional reconstruction by computed tomography of an undifferentiated sarcoma in a dog. J Appl Anim Res 2012; 40(4): 289-91.

14. Jaber JR, Carrascosa C, Arencibia A, Corbera JA, Ramirez AS, Melian C. 3-D computed tomography reconstruction: another tool to teach anatomy in the veterinary colleges. Iran J Vet Res 2018; 19(1): 1-2.

15. Daza JD, Bauer AM. The circumorbital bones of the Gekkota (Reptilia: Squamata). Anat Rec 2010; 293(3): 402-13.

16. Moselhy AA, Mahdy, E. Comparative three dimensionalcomputed tomography (CT) scans and anatomical investigation of rabbit (Oryctolagus cuniculus) and cat (Felis domestica) skull. Slov Vet Res 2019; 56 (Suppl 22): 365-79.

\title{
PRIMERJAVA LOBANJ KOMODOŠKEGA VARANA (Varanus komodoensis) IN ZELENEGA LEGVANA (Iguana iguana) S POMOČJO TRIDIMENZIONALNE RAČUNALNIŠKE TOMOGRAFSKE REKONSTRUKCIJE
}

\author{
S. Pérez, M. Encinoso, M. Morales, A. Arencibia, A. Suárez-Bonnet, E. González-Rodríguez, J. R. Jaber
}

Izvleček: Namen prispevka je bil s tridimenzionalno računalniško tomografsko rekonstrukcijo opraviti primerjalno oceno lobanje dveh vrst kuščarjev, komodoškega varana (Varanus komodoensis) in zelenega legvana (Iguana iguana). Slike, pridobljene s to metodo, prikažejo odlične anatomske podrobnosti lobanje. Zato so bile na stranskih in dorzalnih rekonstrukcijah slik vidne bistvene razlike v zgradbi orbitalnega področja in stranskih kosti nevrokranija med obema vrstama kuščarjev. Slike, pridobljene s tridimenzionalno računalniško tomografsko rekonstrukcijo, so lahko dragocena diagnostična pomoč pri klinični oceni večih napak glave pri kuščarjih.

Ključne besede: računalniška tomografija;3D rekonstrukcija; anatomija; lobanja; kuščarji 